UDC 339.138:656.07

DOI 10.21272/mmi.2018.3-20
JEL Classification: M30, L98, R41

Tetiana Borysova,

D.Sc., Associate Professor,

Head of the Department of Marketing,

Ternopil National Economic University,

Ternopil, Ukraine

Grygorii Monastyrskyi,

D.Sc., Professor,

Management and Public Administration Department,

Ternopil National Economic University,

Ternopil, Ukraine

\title{
MARKETING INNOVATION ACTIVITY OF URBAN PUBLIC TRANSPORT: RESULTS OF THE EMPIRICAL STUDY
}

The problem of finding efficient models of managing the innovation activities of urban public transport providers is relevant in the recognition of innovation as the main principle of the strategy of economic and social development of Ukraine. The purpose of the study is to identify the ways to improve the marketing innovation management process of urban public transport service providers in the regional centers of Ukraine. The purpose has determined the need to solve such problems as to identify the degree of marketing orientation of urban public transport providers of the regional centers of Ukraine; identify problems and outline ways to improve the management of marketing activities of subjects of the national network of the urban public transportation. In January-March 2018, the authors initiated a study on the current state of urban public transport in regional Ukrainian cities. Following this, the requests for public information were submitted in accordance with the Law of Ukraine "On Access to Public Information" to all city councils of Ukraine's regions except temporarily occupied territories. The article analyses the quantitative and qualitative state of the fleet of vehicles, the requirements and the state of their observance by carriers, the level of fares, and the state of information provision of passengers of urban public transport in the regional cities in Ukraine. Empirical data obtained in the course of the study confirmed the appropriateness of the development of customer orientation of urban public transport service providers in terms of improving the quality of the fleet of vehicles (increase of the share of ecological transport and renewal of the fleet of vehicles); strengthening the control of city councils for the quality of services provided by carriers; intensification of cooperation of the city councils with representatives of the civil society within the framework of the Law of Ukraine "On Access to Public Information"; increase in the number of smart stops.

Keywords: marketing, urban public transport, tariff, need, consumer, marketing innovation, market.

Problem statement in general form. Timely, complete and high-quality satisfaction of the needs of the population in transportation is a mission of both carriers and institutions that control and regulate their activities. The interdependence of functional activity of the subjects of the market of urban public transport services causes the existence of the relationship between the individual stages of marketing management of such market agents. Raiko D.V. and Lebedieva L.E. consider marketing management from the standpoint of marketing functions as management of marketing processes in the enterprise, which are related to market research, marketing and promotion of products and services, relate to its commodity and pricing policy, as well as directly organizing the work of the marketing service [1].

The analysis of the scholarly papers [1-5] allowed structuring the process of managing the marketing innovation of urban public transport service providers to the following stages:

1. Analysis of market opportunities and threat assessment, where marketing research is carried out, 
the factors of the marketing environment are assessed, the behavior of consumers is studied;

2. Definition of the target clients, forecasting of volumes of demand, positioning of goods on the market, and market segmentation;

3. Development of the concept of marketing innovation complex in aspects of goods, prices, distribution, promotion, process, personnel, and service delivery environment;

4. Implementation of planned marketing innovation measures and control of their effectiveness.

Recent research and publications analysis. Significant contribution to the development of procedural, conceptual and content components of marketing of transport enterprises was made by Redziuk E.V. (outlined the place of marketing of innovative services in the transport system of Ukraine) [2], Driomin M.S. (explained the applied aspects of marketing in the field of transport services, for example, railway transport) [3], Kreisman E.A. (substantiated the directions of improvement of the method of organization of bus transportations in the cities transport system) [4], Aksenov I.M. (highlighted the organizational aspects of marketing of transport enterprises) [5], Oklander M.A. and Zharska I.O. (disclosed the question of the formation of the marketing system of the railway transport enterprise in modern conditions of Ukraine) [6].

The results of the authors' research confirmed the need for attention to the issues of urban transport on the principles of intellectual technologies in the aspect of marketing. These issues are partly addressed in a series of projects of the Council of Europe Commission on energy efficient transport, namely: "AD PERSONAM Direct Marketing Program", which lasted from 2008 to 2010, "Electric Urban Transport" (ELE. C.TRA), which lasted for 2013-2015, "Towards the Key Challenges for Sustainable Urban Mobility Planning (CH4LLENGE)", which lasted from 2013 until 2016.

The problem of using marketing tools in the management of urban transport was studied by such foreign scientists, including Khayretdinova R. (disclosed the theoretical foundations of the concept "smart city" [7], Caragliu A., Del Bo C., Nijkamp P. (they investigated the experience of "smart" cities of Europe [8], Dickey M. (innovative methods of public transport management) [9], Carvalho L. (vectors of transport management development) [10], Hollands R. (management of the "smart city") [11], Giffinger R. and Gudrun H. (marketing positioning of cities and the role of urban transport in the ranking of cities) [12], Nowicka K. (urban logistics and "cloud" competing model [13 ], Cronin J. Jr. and Hightower R. Jr. (assessment of the role of marketing in public transit organizations) [14].

At the same time, the directions of development of the process of management of marketing of the subjects of the urban public transport market are not sufficiently highlighted. Thus, further studies are needed to provide an opportunity to analyze the prospects of the development of the market of urban public transport services in Ukraine on the basis of the creative implementation of foreign marketing experience and taking into account domestic conditions.

The purpose of the study is to identify the ways to improve the marketing innovation process of urban public transport service providers in the regional centers of Ukraine. The purpose has determined the need to solve such problems as to identify the degree of marketing orientation of urban public transport providers of the regional centers of Ukraine; identify problems and outline ways to improve the management of marketing activities of subjects of the national network of the urban public transportation.

Research results. The area of the urban public transport services is a complex system of relationships between carriers of different forms of ownership, which are providers of services, legislative and executive bodies in the field of transport management, public organizations and consumers of such services. During the study, it was not possible to obtain reliable information on the managerial aspects of the marketing activities of most commercial public transport services providers. However, the operational activity of the urban public transport services providers is largely regulated and controlled by the local authorities and local self-government bodies. Therefore, we believe that information obtained from our research from the city councils of the regional centers of Ukraine allows us to indirectly assess the level of marketing 
orientation, disadvantages and directions for improving the marketing management process of the urban public transport providers.

It is believed that transport service providers, whose management responds to the challenges of the functioning environment through marketing, use marketing tools in the communication process, attract material, financial and labor resources, build and maintain good relationships with subjects and interest groups, that is, they are adhered to marketing orientation. At the same time, such marketing orientation can be differentiated depending on the priorities of management of the transport services providers. Thus, transport service providers may be focused on proposals, on searching sources of financing (maximizing profits) or on the needs [15], [38]. Tabl. 1 presents the key characteristics of these types of the transport service provider orientations.

Table 1 - Key characteristics of the types of the transport service providers orientations (formed on a basis of $[15 ; 38]$ )

\begin{tabular}{|c|c|c|c|}
\hline \multirow{2}{*}{ Characteristics } & \multicolumn{3}{|c|}{ Transport service providers focused on ... } \\
\cline { 2 - 4 } & Suggestions & Receiving profit & Needs \\
\hline Management focus on & services & searching financial sources & target audiences' needs \\
\hline $\begin{array}{c}\text { Search for employees } \\
\text { according to }\end{array}$ & $\begin{array}{c}\text { their awareness of } \\
\text { goods/services }\end{array}$ & $\begin{array}{c}\text { their awareness of } \\
\text { communication methods and } \\
\text { profit optimization }\end{array}$ & $\begin{array}{c}\text { their awareness of } \\
\text { marketing methods }\end{array}$ \\
\hline Problems solutions & $\begin{array}{c}\text { correlate according to } \\
\text { services provided }\end{array}$ & $\begin{array}{c}\text { provide analysing } \\
\text { competitors }\end{array}$ & $\begin{array}{c}\text { are provided in line with } \\
\text { research results }\end{array}$ \\
\hline $\begin{array}{c}\text { Management believes } \\
\text { marketing segmentation }\end{array}$ & $\begin{array}{c}\text { is not required as everyone } \\
\text { understands the importance } \\
\text { and content of the services } \\
\text { given }\end{array}$ & $\begin{array}{c}\text { is important thus the } \\
\text { Is less useful as everyone } \\
\text { can be a target profit market is segmented and } \\
\text { the best target segments } \\
\text { are searched }\end{array}$ \\
\hline $\begin{array}{c}\text { Management is certain } \\
\text { that marketing strategy }\end{array}$ & $\begin{array}{c}\text { must focus on provided } \\
\text { services but no other } \\
\text { elements of the marketing } \\
\text { complex }\end{array}$ & $\begin{array}{c}\text { must be focused on } \\
\text { promotion means in order to } \\
\text { persuade the target audience } \\
\text { to pay }\end{array}$ & $\begin{array}{c}\text { is required for every target } \\
\text { segment, must explain all } \\
\text { elements of the marketing } \\
\text { complex }\end{array}$ \\
\hline
\end{tabular}

The greatest degree of orientation of the transport services providers to marketing reflects the extent to which the latter takes into account the needs of consumers of such services.

At the stage of market opportunity analysis and threat assessment, marketing research is being carried out, the factors of the marketing environment are evaluated, and consumers' behaviour is studied. None of the respondents mentioned the implementation of such measures. We believe that an effective process of managing the marketing activities of transport service providers should be aimed at creating the conditions under which the passenger will be heard by all management levels. In Great Britain, for example, any passenger transport operator can obtain information about its customers from end-users of transport services incorporated in public organizations, such as "Bus Users UK" and "The Confederation for Passenger Transport" [39].

In January-March 2018, the authors conducted a survey by means of a post-poll survey aimed at identifying the degree of marketing orientation of the urban public transport service providers of the regional Ukrainian cities. Among the objectives of the study was to find out how much the quantitative and qualitative composition of the fleet and the fleet of electric vehicles satisfy customers' needs, or information support is sufficient, the amount of funding from local governments and the state, the existence of strategies for the urban public transport, participation in international transport development programs, environmentally friendly level of vehicles and others. In accordance with this, the requests for public information were outlined and submitted following the Law of Ukraine "On Access to Public Information" 
dated from January 13, 2011 No. 2939-VI, to all city councils of Ukraine, except temporarily occupied territories. The analysis of the responses received from the city councils representing all regions of Ukraine [16-37] (except for the city of Dnipro and the temporarily occupied territories of Ukraine) made it possible to draw conclusions, some of which are shown below.

An important stage in the process of managing the marketing activities of the urban public transport services providers is the definition of a target market, which involves the selection of target customers, forecasting demand, positioning the product in the market, and market segmentation. How effective this stage is can be estimated from whether there are enough vehicles to provide such services. To a certain extent, such an indicator may be the number of vehicles, which account for 10 thousand inhabitants, as shown in Fig.1.

Our research revealed that vehicles in most regional cities in Ukraine were insufficient, which made it possible to conclude that there was a lack of customer orientation of the urban public transport service providers. Thus, the number of vehicles (buses and electric vehicles) per 10 thousand inhabitants in the regional centers of Ukraine is not the same: most of the buses belong to the inhabitants of the cities of Kropyvnytskyi and Mykolaiv (19.5 vehicles per 10 thousand inhabitants), the least in Vinnytsia and Odesa; however, the largest number of environmentally friendly electric vehicles per 10 thousand residents in Vinnytsia, Zhytomyr and Khmelnytskyi, and the smallest in Uzhhorod, Sumy, and Odesa.

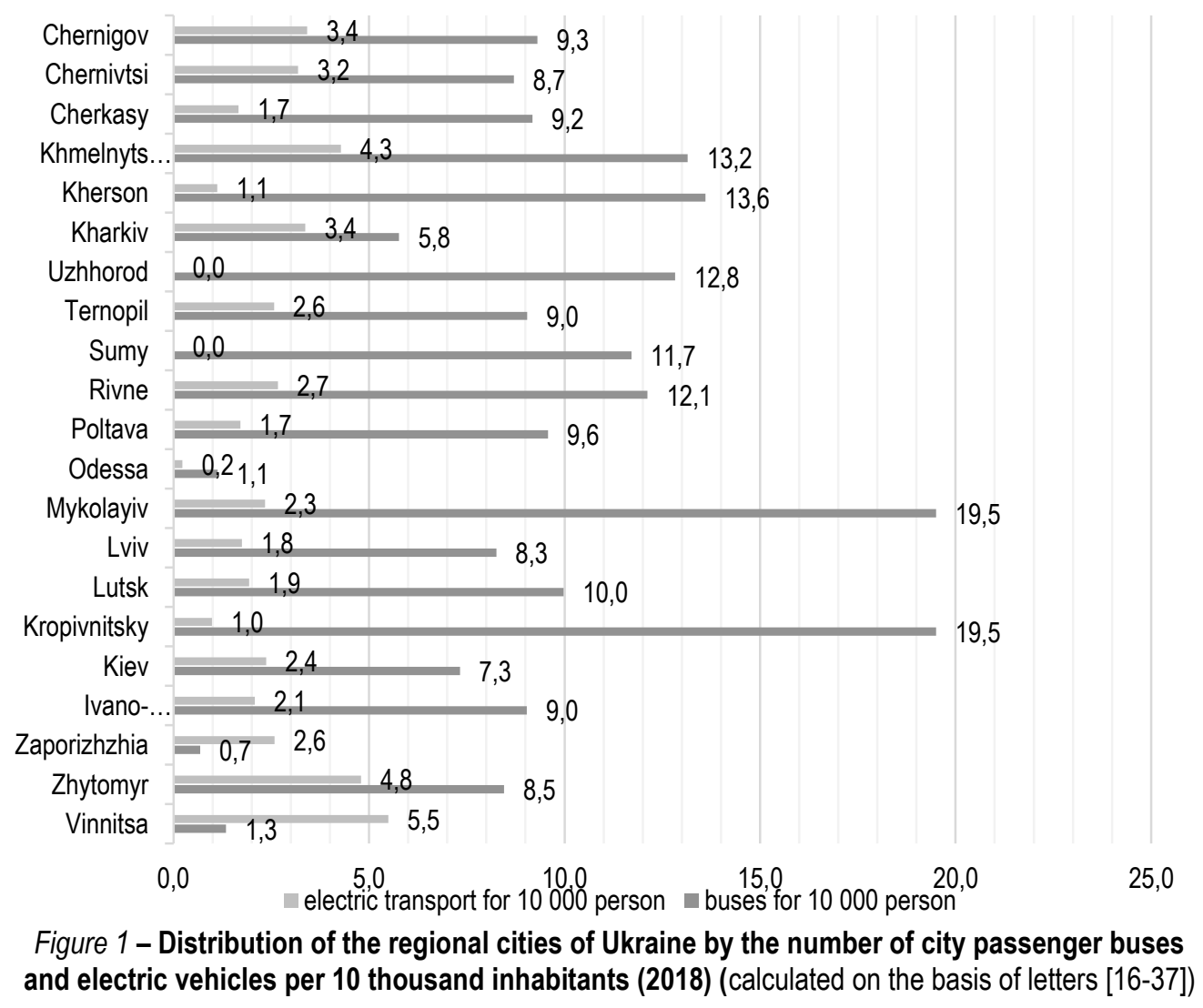


The results of the study showed that the stage of the marketing activities management process, such as the development of the concept of a marketing mix in product aspects, prices, distribution, promotion, process, personnel and service delivery environment, is gaining weight and implemented with varying effectiveness. This stage of the management process in terms of tariff formation and communication is being fully implemented. In a digital society, personal mobile devices have rapidly changed the information sharing paradigm. For example, research on the use of de-personalized Wi-Fi data was conducted on the metro in London to better understand how customers move between stations. The results of the study revealed various travel patterns that helped plan and operate the London Underground more effectively to meet the needs of customers, provide them with better information and reduce traffic congestion [40].

In the developed world, the marketing orientation of carriers and local authorities is aimed at involving passengers in order to take their views into practice. In this case, urban public transport carries out three roles in creating value together using their own mobile devices: they are consumers of information, information providers and information verifiers [41]. At the same time, our research has proven that the potential of the digital revolution has not been completely implemented in the sphere of urban public transport of Ukraine. Thus, the level of provision of "smart" stops is insufficient: as such hubs have not been created in half of the regional cities of Ukraine (Figure 2), however, $82 \%$ of buses and more than $90 \%$ of electric vehicles are equipped with GPS trackers.

Foreign researchers argue that the global trends in public transport development in 2017 were: integrated mobility services, reorganization of the public transport market, use of environmentally friendly transport as an alternative to fossil fuels, motorcycle boom and the growth of their impact on urban mobility [42]. Unfortunately, the issue of environmental friendliness as an important qualitative feature of urban passenger transportation services is not always taken into account when conducting a competition for the formation of a network of the city bus routes.

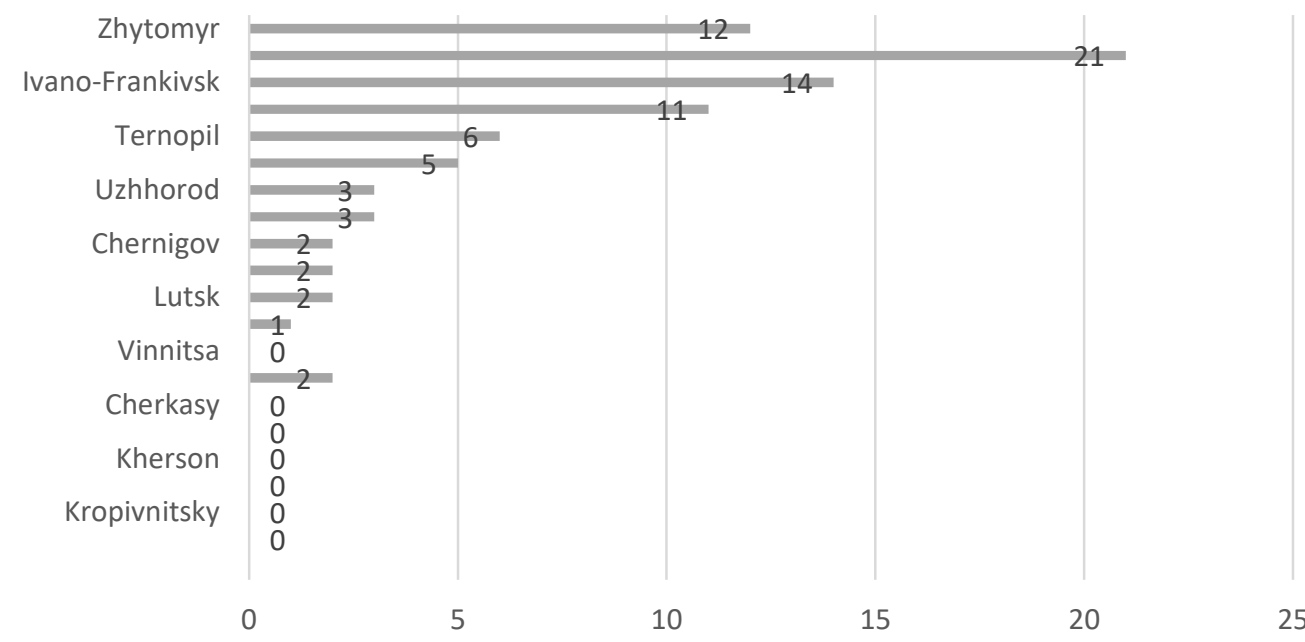

Figure 2 - Number of "smart" stops and the ones equipped with information boards in the regional centers of Ukraine, 2018 (calculated on the basis of letters [16-37])

Only $13 \%$ of the respondents put forward requirement EURO-5 for the competition participants, EURO-4 and EURO-3 - $4 \%$ of the respondents, EURO-2 - $22 \%$ of the polled, the rest did not indicate whether there was such a requirement for potential carriers (Figure 3). 


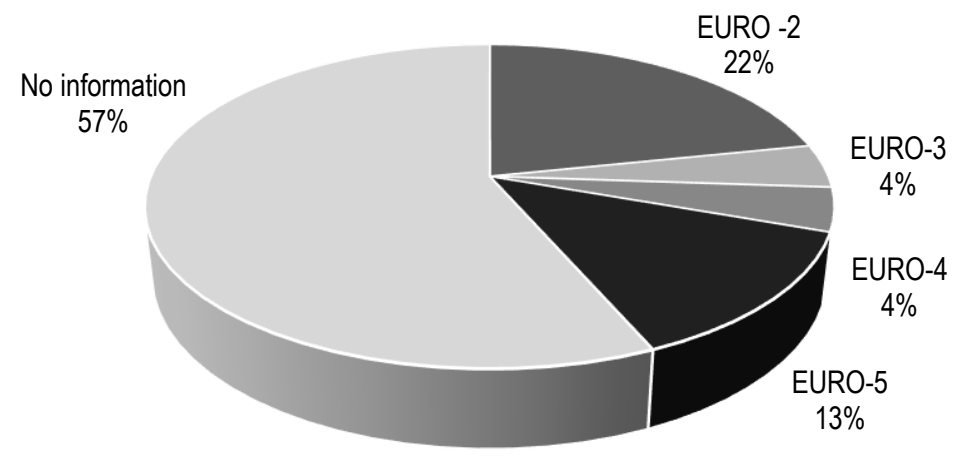

Figure 3 - Ecological requirements for the participants of the competition for the formation of the network of city bus routes of the regional centers of Ukraine, 2018 (calculated on the basis of letters [16-37])

An example of the best practice is the improvement of the quality of transport services through the participation of transport enterprises, city councils or structural subdivisions that are tied to the management of urban public transport in national and international programs, grants, etc., which are aimed at developing and improving the environmental friendliness of public transport of the city (Figure 4). The quality of urban public transport services due to fundraising over 2014-2017 has been improved in the cities of Kropyvnytskyi, Odesa, Sumy, Kharkiv, and Chernihiv.

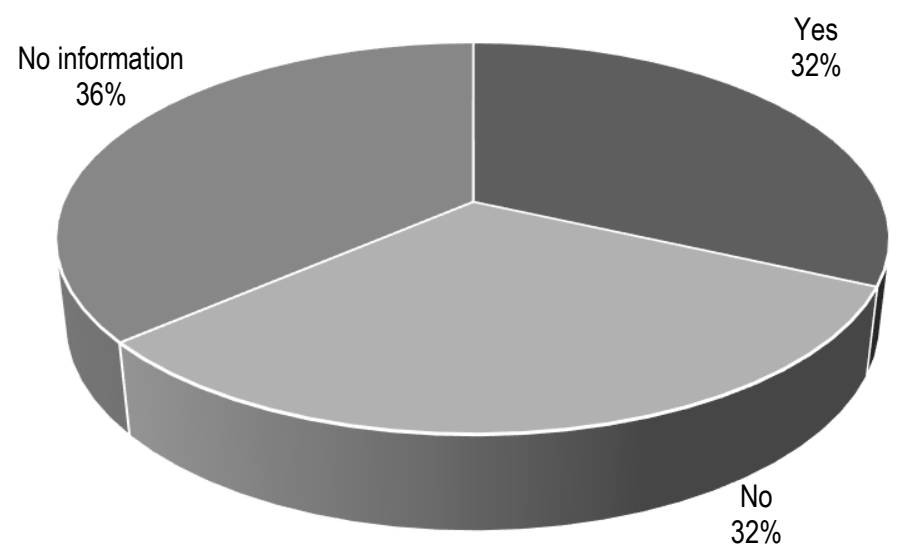

Figure 4-Distribution of the answers to the question: "Did the city council take part in national and international programs, grants, etc. aimed at developing and/or improving the environmental friendliness of public transport in the city during 2014-2017?" (calculated on the basis of letters [16-37])

The existence of a unified city transport management system creates opportunities for transport providers to plan their operations, identify problems and opportunities for customers. The survey revealed that there is practically no single city management system in the cities of Ukraine: $37 \%$ of the respondents 
indicated that there is a single monitoring system, $36 \%$ confirmed the absence of a city management or monitoring system, the rest $27 \%$ of the respondents did not provide the requested information (Fig. 5).

As it can be seen in Fig. 6, in most of the studied cities there is no single ticket to travel in the city public transport (58\% of the respondents), but its implementation has begun: in the cities of Kyiv, Kropyvnytskyi, Ternopil, and Kharkiv, by the beginning of 2018 there was a single ticket for several types of transport, $21 \%$ of the respondents reported implementing of the initial stage of the project.

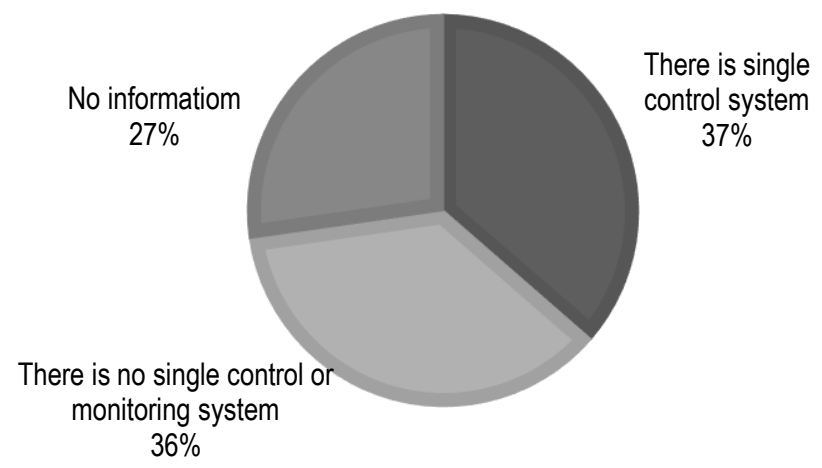

Figure 5 - Distribution of the answers to the question: "Is there a single management system in the city?" (calculated on the basis of letters [16-37])

The information system for passengers in the UK, for example, enables public transport providers to create and distribute information to passengers about their services, as well as transport links via multimedia distribution channels such as electronic displays, travel planning applications, mobile phones, websites, e-mails, SMS, Twitter and Facebook [43].

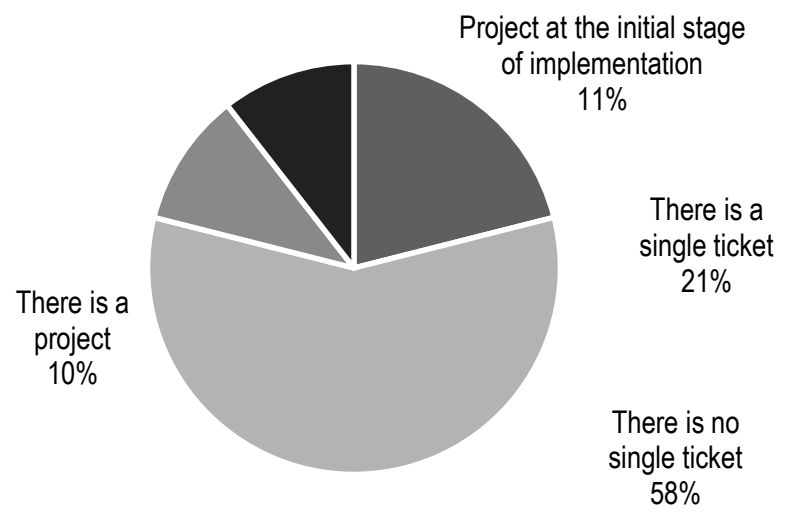

Figure 6-Availability in cities of a single ticket for several types of transport (calculated on the basis of letters [16-37])

An important attribute of services for urban public transport passengers is its safety, which must be provided by carriers, but controlled by authorized bodies, including city councils. Unfortunately, about half 
of the respondents did not provide the requested information about the inspections, as shown in Fig. 7.

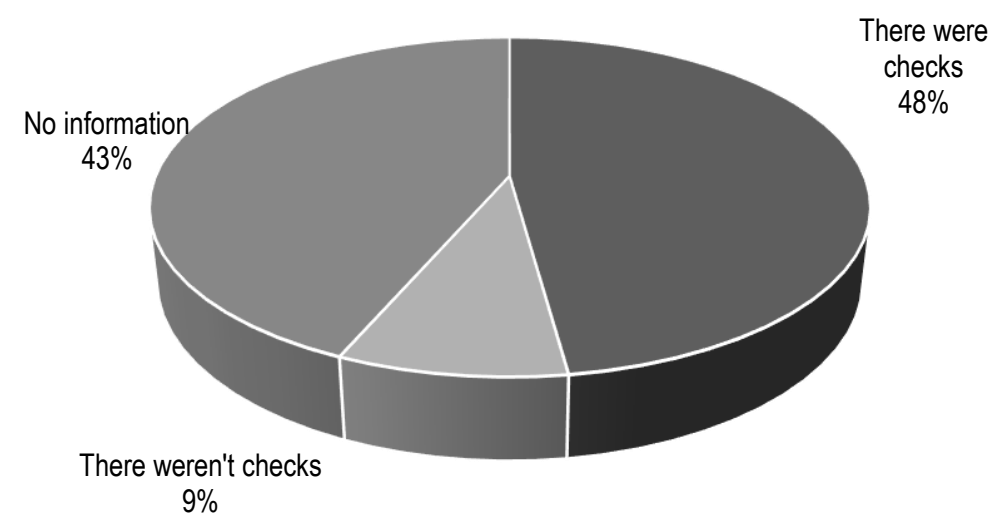

Figure 7 - Distribution of the answers to the question: "Did the city council carry out a services quality check on the urban public transport providers?" (calculated on the basis of letters [16-37])

A positive step towards the growth of customer orientation of the urban public transport service providers is the draft resolution of the Cabinet of Ministers of Ukraine, developed by the Ministry of Infrastructure of Ukraine. The draft resolution envisages changes to the Rules for the provision of passenger road transport services, namely, since January 2020, the use of buses for converted cargo vehicles for the carriage of passengers, except for converted M2 category buses designed for the carriage of exclusively seated passengers on irregular routes up to 80 kilometers with a certificate of conformity of a wheeled vehicle issued by the certification authority by the Ministry of Infrastructure [44].

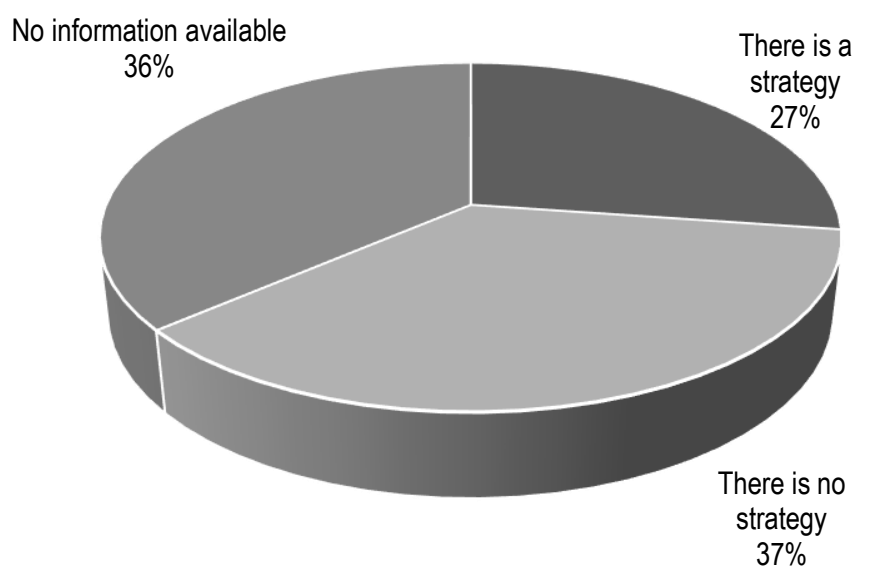

Figure 8 - A strategy or program of public transport development in the investigated city councils of Ukraine, 2018 (calculated on the basis of letters [16-37])

The price as an element of the urban public transport provider marketing mix is differentiated by the type of vehicles and is determined by the decisions of the city council committee. In Tabl. 2 the tariffs for 
passenger transportation services on public bus routes and passenger electric transport in the regional centers of Ukraine at the beginning of 2018 are indicated.

Table 2 - Tariffs for passenger transportation in urban public transport (full ticket) in the cities of Ukraine (calculated on the basis of letters [16-37])

\begin{tabular}{|l|c|c|c|c|c|c|c|}
\hline \multirow{2}{*}{ Cities } & \multicolumn{7}{|c|}{ Ticket prices by type of public transport, UAH. } \\
\cline { 2 - 8 } & Bus & Shuttle bus & Trolleybus & Tram & Metro & Commuter train & Cable car \\
\hline Vinnitsa & 3,50 & 4,00 & 3,00 & 3,00 & - & - & - \\
\hline Dnipro & 3,$50 ;$ & - & - & - & - & - & - \\
& 7,00 & & & & & & - \\
\hline Zhytomyr & 5,00 & 5,00 & 3,00 & - & - & - & - \\
\hline Zaporozhye & 4,00 & - & 3,00 & 3,00 & - & - & - \\
(Zaporizhialectrotrans) & & & & & & & - \\
\hline Ivano-Frankivsk & 4,00 & - & 2,00 & - & - & - & - \\
\hline Kiev & 4,00 & 7,00 & 4,00 & 4,00 & 5,00 & 5,00 & 4,00 \\
\hline Kropivnitsky & 4,00 & 4,50 & 2,50 & - & - & - & - \\
\hline Lutsk & 4,00 & 4,00 & 2,00 & - & - & - & - \\
\hline Lviv & 5,00 & 5,00 & 3,00 & 3,00 & - & - & - \\
\hline Mykolayiv & - & - & - & - & - & - & - \\
\hline Odessa & - & 7,00 & 3,00 & 3,00 & - & - & - \\
\hline Poltava & 5,00 & - & 3,00 & - & - & - & - \\
\hline Rivne & - & 4,00 & 2,00 & - & - & - & - \\
\hline Sumy & 3,50 & 5,00 & 2,50 & - & - & - & - \\
\hline Ternopil & 5,00 & 5,00 & 4,00 & - & - & - & - \\
\hline Uzhhorod & 4,00 & - & - & - & - & - & - \\
\hline Kharkiv & 1,00 & $4,25-8,00$ & 3,00 & 3,00 & 4,00 & - & - \\
\hline Kherson & - & 4,00 & 2,50 & - & - & - & - \\
\hline Khmelnytskyi & 4,00 & - & 2,50 & - & - & - & - \\
\hline Cherkasy & 4,00 & - & 2,00 & - & - & - & - \\
\hline Chernivtsi & - & 4,00 & 2,00 & - & - & - & - \\
\hline Chernigov & 4,50 & - & 3,00 & - & - & - & - \\
\hline & & & & & & & \\
\hline
\end{tabular}

An important stage in the management process of the marketing activities is the implementation of planned marketing events and their effectiveness control. Considering the marketing strategy of service providers as part of a higher-level strategy and strategy for urban public transport development of city councils (Fig. 8), it was established that only in 9 regional centers of Ukraine a strategy or program was developed that contains elements of a marketing strategy for the development of public utilities of urban public transport: Urban Electric Transport Development Program of Cherkasy for 2017-2020, Urban Passenger Transport Development Program in Kherson for 2018-2023, City Electric Transport Development Program for Khmelnytskyi for 2016-2020, Strategy of Economic and Social Development of Odessa City until 2022, Poltava City Electrification Development Program for 2018-2020, Program for the Development of Lutsk Electric Transport Enterprise for 2016-2020, Program for the Development of the Communal transport of Ivano-Frankivsk for 2018-2022, Development strategy of the city of Kyiv until 2025, Integrated program of development of urban passenger transport in Vinnytsia for 2018-2023. Thus, planning of marketing events and increasing customer orientation of most regional centers of Ukraine is not integrated into the city's development strategy.

Conclusions. The results of the empirical research indicate fragmentation of the use of management of marketing innovation activities and the satisfactory level of client orientation of the urban public transport 
providers. The combined analysis of the received information from the transport departments of the city councils of the regional centers of Ukraine revealed the lack of information regarding the operation of transport service providers who are the winners of the competition for the formation of a network of urban transportation. In addition, more than half of the city councils of the regional centers of Ukraine did not confirm that they carried out quality checks on the services of the urban public transport carriers during 2015-2017, that is, the issue of ensuring an adequate level of service quality is relevant. With such results we managed to propose the priority directions of improvement of the marketing management process of the urban public transport providers of the regional cities in Ukraine:

- firstly, it is necessary to strengthen the planning, evaluation and control unit of marketing activities by identifying a marketing component in urban transport development strategies and programs, and planning of corporate and functional strategies of utility companies to carry out in their flow;

- secondly, the high level of GPS-trackers of urban vehicles provision creates preconditions for the introduction of a unified city public transport management system, which will help to optimize the time and financial costs of both providers and consumers of such services. In addition, it will also contribute to the integration of information blocks of service providers, improving the efficiency of marketing information, the effectiveness of the marketing information system and automated information system;

- thirdly, it is necessary to strengthen the cooperation of the structural units of city councils, related to the issues of transport management, with the providers of urban public transport in order to improve customer orientation in aspects of increasing awareness of passengers, strengthening the control of the city councils on the quality of provided services, conducting passenger surveys for the purpose of research of the level of service quality (survey methodology is presented in [45]), event marketing (organization of the Day of Urban Public Transport, the Day of Ecological Transport), increasing customer loyalty to environmental transport through strengthening communication policy, the introduction of a single ticket for several modes of transport. In addition, the concept of social-ethical marketing involves ensuring high environmental friendliness of vehicles, which requires intensification of fundraising by the city councils.

Thus, according to the results of the empirical study:

1. The fragmentary use of marketing activities management and the satisfactory level of client orientation of urban public transport providers, lack of awareness of structural units on transport in relation to the operation of transport service providers, and the lack of control over the quality of transport services in most Ukrainian cities are established;

2. The expediency of strengthening cooperation between municipal authorities and private carriers in the aspects of joint strategic marketing activity, the increase of environmentally friendly services, the formation of a unified information system are substantiated;

3. The following directions of improvement of the marketing innovation management process of urban public transport service providers of the regional cities of Ukraine, such as increasing the awareness of passengers, strengthening the control of the city councils for the quality of services are provided. They foresee conducting passenger surveys for the purpose of studying the level of service quality, event marketing, increasing customer loyalty to ecological transport due to the strengthening of communication policy, the introduction of a single ticket for several types of transport, and attracting consumers to the routes and tariff formation.

The authors further attributed the further development of research of development of marketing communication activity of urban public transport providers' services.

Gratitude. The authors express their gratitude to the Ministry of Education and Science of Ukraine, with the support of which an article was published in the framework of the scientific work of young scientists on the topic: "Formation of the mechanism of sustainable urban transport development based on the concept of "smart" city and municipal ecological logistics" (state registration number 0117U003871). 
1. Raiko, D. V., \& Lebedieva, L. E. (2015). Model upravlinnya marketyngom u systemi menedzhmentu promyslovogo pidpryyemstva [Model of marketing management in management system of industrial enterprise]. Marketing and Management of Innovations,(1), 107-123. Retrieved August 20,2018, from http://mmi.fem.sumdu.edu.ua/sites/default/files/mmi2015_1_107_123.pdf [in Ukrainian].

2. Redzjuk, E. V. (2006). Marketynh innovacijnyx posluh v systemi transportu Ukrajiny (na prykladi naukovo-doslidnyx instytutiv sfery transportu) [Marketing of innovative services in the transport system of Ukraine (on the example of research institutes of the sphere of transport)] (Doctoral dissertation, Uzhhorod National University) [Abstract]. (UMI No. 08.06.01) [in Ukrainian].

3. Dr'omin, M. S. (2006). Marketynh u sferi transportnyx posluh (na prykladi pidpryjemstv zaliznyčnoho transportu) [Marketing in the field of transport services (for example, rail transport enterprises)] (Doctoral dissertation, Kyiv National Economics University named after Vadym Hetman) [Abstract]. (UMI No. 08.06.01) [in Ukrainian].

4. Kreisman, E. A. (2002). Udoskonalennya metodyky orhanizatsiyi avtobusnykh perevezen' $v$ transportniy systemi mist [Improvement of the methodology of the organization of bus transportation in the transport system of cities] (Doctoral dissertation, Kyiv National Transport University [Abstract]. (UMI No. 05.22.01) [in Ukrainian].

5. Aksenov, I. M. (2013). Orhanyzacyja marketynha na obъektax transporta [Organization of marketing on objects of transport]: Monograph. Khmelnitsky: KhNU [in Russian].

6. Oklander, M. A., \& Zharska, I. O. (2010). Marketynhovi aspekty reformuvannja zaliznyčnoho transportu [Marketing aspects of rail transport reform]: Monograph. Odessa: Astroprint [in Ukrainian].

7. Hajretdynova, R. S. (2014). Teoretycheskye osnovy koncepcyy «umnyi horod» y osobennosty jeje adaptacyy v rehyone [Theoretical foundations of the concept of "smart city" and its features adaptation in the region]. Russian Entrepreneurship, (20 (266)), 101-106 [in Russian].

8. Caragliu, A., Del Bo, C., \& Nijkamp, P. (2009). Smart cities in Europe. In Proceedings of the 3rd Central European Conference in Regional Science(pp. 49-59). Košice, Slovak Republic. Retrieved September 25, 2018, from http://www.cers.tuke.sk/cers2009/PDF/01_03_Nijkamp.pdf.

9. Dickey, M. R. (2013, December 18). That Helps You Avoid Crowded Subways and Buses, Just Raised \$28 Million. Business Insider. Retrieved September 25, 2018, from http://www.businessinsider. com/moovit raises-28-million-2013-12.

10. Carvalho, L. (2015). Smart cities from scratch? A socio-technical perspective. Cambridge Journal of Regions, Economy and Society, (8), 43-60.

11. Hollands, R. (2015). Critical interventions into the corporate smart city. Cambridge Journal of Regions, Economy and Society, (8), 61-77.

12. Giffinger, R., \& Gudrun, H. (2010). Smart cities ranking: An effective instrument for the positioning of cities? (4 (12)), 7-25 Retrieved September 25, 2018, from http://upcommons.upc.edu/revistes/bitstream/2099/8550/7/A CE_12_SA_10.pdf.

13. Nowicka, K. (2014). Smart City logistics on cloud competing model. Procedia Social and Behavioral Sciences, 151, 266281.

14. Cronin, J. J., \& Hightower, R. J. (2004). An Evaluation of the Role of Marketing in Public Transit Organizations. Journal of Public Transportation,7(2). Retrieved August 20, 2018, from https://www.nctr.usf.edu/jpt/pdf/JPT 7-2 Hightower.pdf.

15. Borysova, T. M. (2016). Marketynh nekomercijnyx subjektiv: teoretyčno-metodolohični aspekty [Marketing of non-profit subjects: Theoretical and methodological aspects]: Monograph. Ternopil: Pidruchnyky i posibnyky [in Ukrainian].

16. Letter from the Vinnitsa City Council No. 01-00-019-13316 dated March 26, 2018.

17. Letter from the Dnipro City Council No. 5/ 3-339 dated March 27, 2018.

18. Letter from the Zhytomyr City Council No. 17 / 3216 dated May 07, 2018.

19. Letter from Ivano-Frankivsk City Council No. 20 / 01-20 / 1072 dated March 26, 2018

20. Letter from the Kyiv City Council (Kyiv City State Administration) No. 053-1707 dated March 02, 2018.

21. Letter from the Mykolaiv municipal enterprise of city electric transport «Mykolaivelectrotrans» No. 467 dated March 06 2018.

22. Letter from the Zaporizhzhya municipal enterprise of city electric transport «Zaporizheelectrotrans» No. 19 / 4-775 dated March 28, 2018.

23. Letter from the Lutsk City Council No. 0-26 / 198 dated March 23, 2018

24. Letter from the Lviv City Council No. 2503-877 dated March 7, 2018.

25. Letter from the City Council of Kropivnitsky No. 145 / 07 dated March 01, 2018.

26. Letter from the Odessa City Council No.12/01-42-1C(ZP-ch) dated March 20, 2018

27. Letter from the Poltava City Council No. 13-24 / zi-5 dated March 01, 2018.

28. Letter from the Rivne City Council No. 13-16 dated March 5, 2018.

29. Letter from the Sumy City Council No. 98 / 03.02.03-02 dated March 22, 2018

30. Letter from the Ternopil City Council No. 955 / 01-10 dated March 27, 2018.

31. Letter from the Uzhgorod City Council No. 115 / 03-23 dated March 14, 2018.

32. Letter from the Kharkiv City Council No. 55 / 0 / 188-18 dated March 27, 2018.

33. Letter from the Kherson City Council No. 8-2291-18 / 23 dated March 28, 2018.

34. Letter from Khmelnytsky City Council No. 12-0986-02-18 dated March 21, 2018

35. Letter from the Cherkasy City Council No. 19531-01-9 dated March 02, 2018. 
36. Letter from the Chernivtsi City Council No. 03/01-11/1121 dated March 22, 2018.

37. Letter from the Chernihiv City Council No.1-24/1-57/76 dated March 19, 2018.

38. Wymer, W. J., Knowles, P., \& Gomes, R. (2006). Nonprofit Marketing: Marketing Management for Charitable and Nongovernmental Organizations. Thousand Oaks, California: Sage Publications.

39. Walters, C. (2017). The voice of today's passenger. Eurotransport,15(1), 8-9.

40. Everitt, V. (2017). Capitalising on emerging data. Eurotransport,15(2), 27.

41. Nunes, A. A., Galvão, T., \& Cunha, J. F. (2014). Urban public transport service co-creation: Leveraging passenger's knowledge to enhance travel experience. Procedia-Social and Behavioral Sciences,(111), 577-585.

42. Public Transport Trends 2017. (n.d.). Retrieved August 20, 2018, from URL: http://www.uitp.org/public-transport-trends.

43. Umpleby, G. (2017). How passenger information contributes to passenger satisfaction. Eurotransport,15(4), 17-19.

44. Ministerstvo infrastruktury initsiiuie zminy do pravyl nadannia posluh pasazhyrskoho avtomobilnoho transportu [The Ministry of Infrastructure initiates amendments to the rules for the provision of passenger road transport services]. (2018, August 17). Retrieved August 20, 2018, from URL: https://mtu.gov.ua/news/30077.html [in Ukrainian].

45. Borysova, T. M. (2017). Otsinka yakisnykh parametriv posluh nadavachiv miskoho hromadskoho transportu Ternopolia rezultaty empirychnoho doslidzhennia [Estimation of quality parameters of the public transportation services by Ternopil customers: Results of empirical study]. Ukrainian Journal of Applied Economics,2(3), 8-15 [in Ukrainian].

T. М. Борисова, д.е.н., доцент, Тернопільський національний економічний університет (Тернопіль, Україна);

Г. Л. Монастирський, д.е.н., професор, Тернопільський національний економічний університет (Тернопіль, Україна). Інновації в маркетингу послуг міського громадського транспорту: результати емпіричного дослідження

Метою дослідження є виявлення напрямків удосконалення процесу управління маркетинговими інноваціями надавачів послуг міського громадського транспорту обласних центрів України. Поставлена мета зумовила необхідність розв'язання таких завдань: виявити ступінь маркетингової орієнтації надавачів послуг міського громадського транспорту обласних центрів України; виявити проблеми та окреслити інноваційні напрями покращення процесу управління маркетинговою діяльністю суб'єктів вітчизняної мережі міських громадських перевезень. Методом дослідження було письмове опитування респондентів. Встановлено фррагментарне використання управління маркетинговою діяльністю та задовільний рівень клієнтоорієнтованості надавачів послуг міського громадського транспорту, недостатню поінформованість структурних підрозділів з питань транспорту стосовно операційної діяльності надавачів транспортних послуг, відсутність контролю за якістю транспортних послуг у більшості міст України. Обгрунтовано доцільність посилення співпраці муніципальних органів та приватних перевізників щодо спільної стратегічної маркетингової діяльності, підвищення екологічності послуг, створення єдиної індрормаційної системи. Запропоновано такі напрями покращення процесу управління маркетинговою інноваційною діяльністю надавачів послуа міського громадського транспорту міст обласного значення України, як підвищення поінфоормованості пасажирів, посилення контролю міських рад за якістю надаваних послуд, проведення опитувань пасажирів з метою дослідження рівня якості послуг, подієвий маркетине, підвищення лояльності клієнтів до екологічного транспорту через посилення комунікаційної політики, впровадження єдиного квитка на декілька видів транспорту, залучення споживачів до процесу формування маршрутів та тарифоотворення.

Ключові слова: маркетинг, міський громадський транспорт, тариф, потреба, споживач, маркетингові інновації, ринок. 